\title{
Inheritance of abnormal erythrocyte cation transport in essential hypertension
}

\author{
PHILIPPE MEYER, RICARDO P GARAY, CORINNE NAZARET, GEORGES DAGHER, \\ MARC BELLET, MICHEL BROYER, JOSUÉ FEINGOLD
}

\begin{abstract}
Net fluxes of sodium and potassium ions were determined in sodium-loaded, potassium-depleted erythrocytes from 370 white subjects, 194 of whom had essential hypertension or had been born to parents with essential hypertension. Findings were compared with those in 86 controls who were normotensive and did not have a family history of hypertension.

Compared with controls all patients with essential hypertension had a low sodium to potassium ratio secondary to a deficit in the sodium-potassium cotransport system. A similar abnormality was found in subjects born to parents with essential hypertension, the prevalences of a deficient cotransport system in such subjects being $53.6 \%$ (52 out of 97) among those with one hypertensive parent and $73.7 \%$ (14 out of 19) among those with two hypertensive parents. Both sexes were equally affected.

Studies in 14 families over two or three generations showed the erythrocyte cation abnormality in one or more members of each consecutive generation. No close association was evident between the deficient erythrocyte sodium-potassium cotransport system and either blood groups ABO, $R$ h, Kidd, Duffy, $P$, and MNS or the major histocompatibility HLA antigens. Out of 90 consecutive unrelated and normotensive white blood donors, 36 showed a low erythrocyte sodium-potassium net flux ratio.
\end{abstract}

It is concluded that in white people abnormal erythrocyte cation transport is a biochemical disorder characteristic of essential hypertension and transmitted by a dominant and autosomal mode expressing a single abnormal gene.

\section{Introduction}

The genetic transmission of essential hypertension in man is well documented, ${ }^{12}$ but no specific genetically coded biochemical abnormality has been described. Studies on erythrocytes from patients with essential hypertension ${ }^{3}{ }^{4}$ and genetically hypertensive rats ${ }^{5}$ showed a defect in the sodium and potassium cotransport system ${ }^{6}$ and increased sodium and potassium countertransport, ${ }^{7}$ which may have the characteristics of a genetic marker of essential hypertension.

INSERM U7/CNRS LA318 Research Unit, Department of Nephrology, Hôpital Necker, 75015 Paris

PHILIPPE MEYER, MD, professor of experimental medicine

RICARDO P GARAY, MD, MS

CORINNE NAZARET

GEORGES DAGHER, MS

Department of Paediatrics, Hôpital Necker-Enfants Malades, 75015 Paris

MARC BELLET, MD

MICHEL BROYER, professor of paediatrics

Centre International de l'Enfance, Château de Longchamp, Paris JOSUÉ FEINGOLD, MD
We report a large-scale investigation to determine the prevalence of abnormal sodium and potassium cotransport in the population, whether it is associated with essential hypertension, and how it is transmitted.

\section{Subjects and methods}

Net fluxes of sodium and potassium ions were measured in sodiumloaded, potassium-depleted human erythrocytes, as described. ${ }^{346}$ Control net flux ratios of sodium to potassium were obtained in 86 normotensive white subjects without a family history of hypertension. Net flux ratios $25 \%$ or more below the mean control value were regarded as abnormal. A normal net flux ratio was indicated by a "negative" erythrocyte test result, and a reduced ratio by a "positive" result.

Blood groups ABO, Rh, Kidd, Duffy, $\mathrm{P}$, and MNS were determined by standard techniques ${ }^{8}$ at the Centre National de Transfusion Sanguine, Hôpital Saint-Antoine, Paris. Major histocompatibility HLA typing was performed at the Institut de Recherches sur les Maladies du Sang, Hôpital Saint-Louis, Paris, by standard microlymphocytotoxicity methods. ${ }^{9}$

SUBJECTS

Seventy-three patients with essential hypertension (42 male, 31 female; mean age 46 years) and 297 normotensive subjects (156 male, 141 female; mean age 39 years) were studied. Secondary causes of hypertension were excluded by careful investigation, including routine blood and urine studies and intravenous pyelography. No patient was in heart failure or had renal insufficiency. All subjects were eating a full diet, and none of the patients had taken an antihypertensive drug before blood sampling. All patients were white. The 86 controls were carefully selected to ensure that both parents were normotensive, that no death secondary to hypertension had occurred in the family, and that all their living relatives were normotensive.

Blood pressure was measured supine with a mercury manometer, and with a Doppler device and appropriate-size cuff in children: Readings were taken two or three times at weekly intervals and the mean used as the actual value. Subjects aged 18 and over were considered to be hypertensive when the systolic pressure exceeded $160 \mathrm{~mm} \mathrm{Hg}$ or the diastolic pressure exceeded $95 \mathrm{~mm} \mathrm{Hg}$. Those under 18 were regarded as hypertensive when pressures exceeded the 95th percentile of the age-related distribution of blood pressure in French children. ${ }^{10}$

\section{FAMILY STUDIES}

Details were obtained on 14 families, and 78 members ( 38 female, 40 male) were available for blood sampling. Samples were obtained from members of three generations in three families (mean age of the oldest generation $72 \pm 3$ years) and from members of two generations in nine. Of all 78 subjects whose blood was examined, 32 were hypertensive. Twenty-five of these were adults (13 men, 12 women; mean age 49 years), and the remainder (six boys and one girl) were aged between 2 and 18 years (mean 12 years). All subjects were eating a free diet, and none had taken an antihypertensive drug before blood sampling.

POPULATION SAMPLES

The study population was divided into three subgroups. Subgroup 1 comprised 97 subjects who had one parent with essential 
hypertension. These subjects ( 46 men, 51 women; mean age 23 years) were investigated as above. A complete familial investigation including all first-degree relatives, however, could not be done. Sixty subjects were normotensive, and 37 had essential hypertension.

Subgroup 2 comprised 19 subjects, both of whose parents had essential hypertension. Of these subjects (10 male, nine female; mean age 25 years), four were hypertensive and 15 normotensive. Again, some first-degree relatives could not be examined.

Subgroup 3 comprised 90 consecutive adult blood donors attending the Necker Hospital. Subjects were unrelated, white, and not receiving medication at the time of blood sampling. Mean age was 29 years. None had hypertension.

\section{BLOOD GROUPS AND HLA TYPING}

In 21 members of three of the 14 families the major histocompatibility HLA complexes were determined; 30 members of five families had their blood group systems checked.

\section{Results}

FAMILY STUDIES

Figure 1 shows the pedigrees of the 14 families. Of the 78 members whose blood was sampled, 39 were in the youngest generations (mean age $19+2$ years): of these, 10 were hypertensive. Of the 39 members of other generations (mean age $50 \pm 2$ years), 22 had essential hypertension. All hypertensive subjects, independent of age and sex, had a positive erythrocyte test result ; in rare instances (two observations) both parents were normotensive but a positive erythrocyte test result was found in one of them. Of the 29 normotensive subjects in the youngest generation, 14 had a positive erythrocyte test result. Thus the erythrocyte abnormality was detectable in one or more members of successive generations in these families.

\section{POPULATION SAMPLES}

The prevalence of positive erythrocyte test results was greatly increased when one or both parents were hypertensive (table I). Of the 90 consecutive blood donors tested, 36 had a positive result.

\section{BLOOD GROUPS AND HLA HAPLOTYPES}

Five families were studied for linkage between a defect in erythrocyte sodium-potassium transport and blood group systems. Lod scores were computed as described. ${ }^{11}$ No close linkage was observed between the defect and the six blood group loci examined (table II). Scores with the Duffy blood group, however, were slightly positive.

Despite the small number of families investigated, certain results clearly established that the gene which codes for the alteration of the erythrocyte membrane is not close to the HLA locus. In all three

TABLE I-Prevalences of reduced erythrocyte sodium-potassium net flux ratios (as indicated by positive erythrocyte test results) among subjects born to normotensive and hypertensive parents

\begin{tabular}{|c|c|c|c|}
\hline & Controls & $\begin{array}{c}\text { One parent } \\
\text { hypertensive }\end{array}$ & $\begin{array}{l}\text { Both parents } \\
\text { hypertensive }\end{array}$ \\
\hline $\begin{array}{l}\text { No of subjects } \\
\text { No }(\%) \text { with positive result }\end{array}$ & ${ }_{3}^{86}(3.5)$ & $\begin{array}{l}97 \\
52(53 \cdot 6)\end{array}$ & $\begin{array}{l}19 \\
14(73 \cdot 7)\end{array}$ \\
\hline
\end{tabular}

TABLE II-Linkage between loci of six blood group systems and low erythrocyte net flux ratio of sodium to potassium ions*

\begin{tabular}{lccr}
\hline Locus & $\begin{array}{c}\text { No of } \\
\text { families }\end{array}$ & \multicolumn{2}{c}{ Genetic distance $(0)$} \\
\cline { 3 - 4 } & 4 & -2.05 & -0.10 \\
\hline ABO & 5 & -0.74 & -1.60 \\
MNSs & 4 & -2.13 & -0.19 \\
Rh & 4 & 0.23 & -1.28 \\
Duffy & 4 & -0.19 & -0.00 \\
Kidd & 3 & -3.10 & -2.08 \\
P & 3 & \\
\hline
\end{tabular}

*Lod scores calculated as described by Morton. ${ }^{11}$

families studied (fig 2) hypertension or a positive erythrocyte test result, or both, was associated with different HLA haplotypes-A28B12 in family A; A3-B16 or A9-B5 in family B; A33-B14-Dr1 in family C. In family C, A33-B14-Drl was also observed in a normotensive child who showed no evidence of abnormal sodium-potassium transport. In family $B$ the HLA haplotype of one hypertensive subject (II 3) was A2-B17/A9-B5, suggesting that the gene coding for the erythrocyte abnormality and hypertension could be close to the A9-B5 haplotype. Hypertensive subject II 2 was A2-B17/A3-B16, however, indicating that the hypertensive gene is far enough away from the A9-B5 haplotype to "cross over" and be found linked with A2-B17 or A3-B16.
FIG 1-Distribution of essential hypertension in 14 families, and results of erythrocyte tests in 78 members.
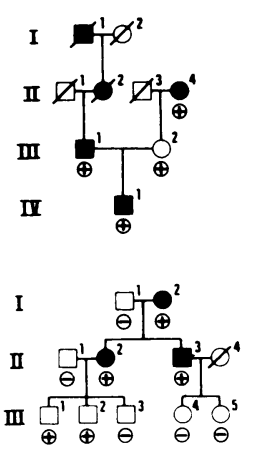
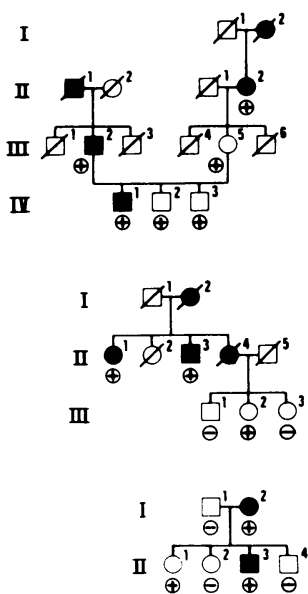
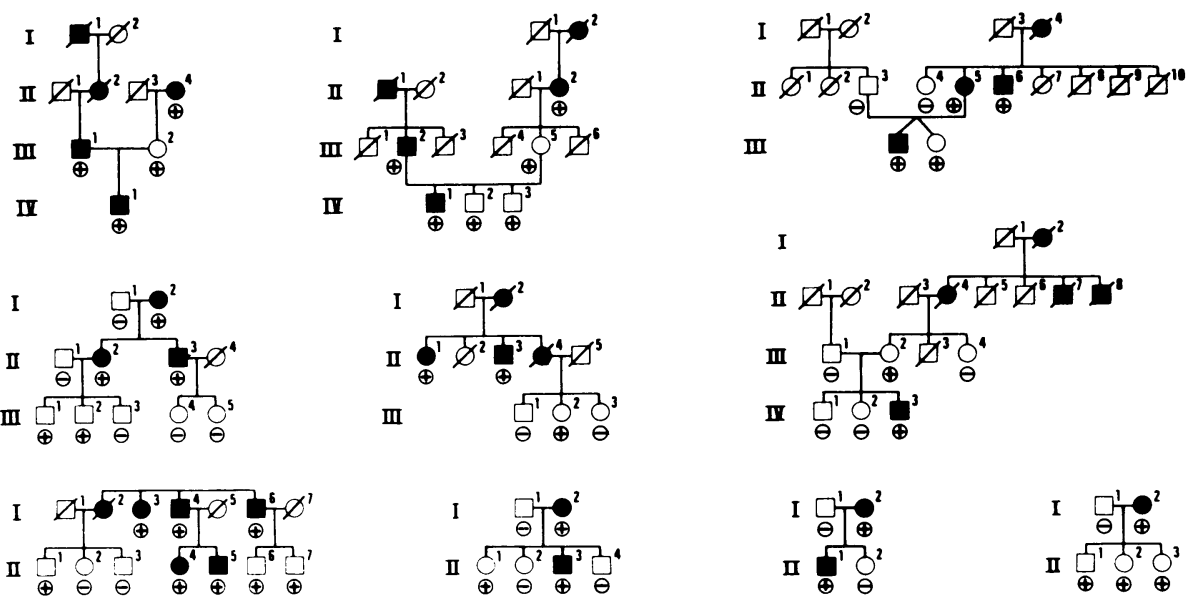
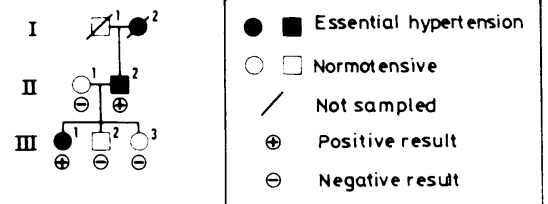


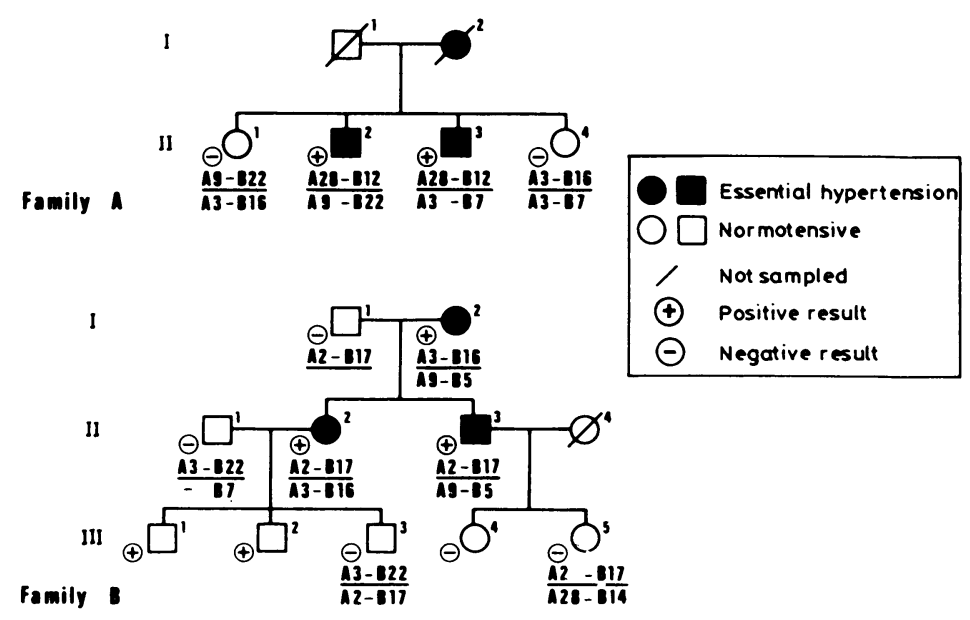

FIG 2-Distribution of essential hypertension, results of erythrocyte tests, and major histocompatibility HLA haplotypes in three families.

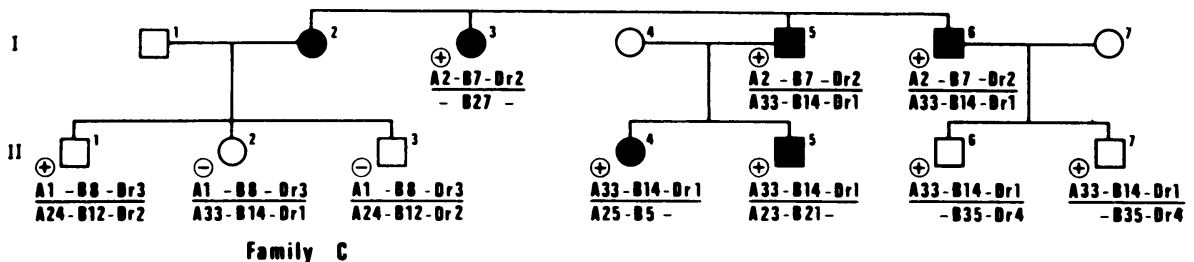

\section{Discussion}

Essential hypertension appears to be a multifactorial disease resulting from the interaction of genetic and environmental factors, ${ }^{12}{ }^{13}$ among which an excessive sodium intake is the most important. We recently showed that the extrusion of a sodium load from erythrocytes of hypertensive patients is inversely correlated with the severity of hypertension. ${ }^{3}$ At the molecular level the extrusion of an erythrocyte sodium load is accomplished by the sodium-potassium pump, sodium-potassium cotransport acting against passive sodium permeability. Kinetic analysis of these sodium transport pathways showed defective sodium extrusion by the sodium-potassium cotransport system in erythrocytes from patients with essential hypertension. In genetically hypertensive rats sodium extrusion from sodiumloaded erythrocytes is also impaired, ${ }^{5}$ resulting in increased intracellular sodium secondary to acute or chronic sodium loading ( $M$ de Mendonca, R P Garay, D Ben-Ishay, P Meyer, Hypertension (in press)).

These data suggest that the membrane abnormality resulting in increased intracellular sodium is characteristic of primary hypertension and closely associated with its genetic transmission. The increase of intracellular sodium may also be of great pathogenic significance, particularly in the excitable cells concerned in the mechanism of hypertension; and results of other workers suggest defective sodium handling in vascular smooth muscle. ${ }^{1415}$ Hence the membrane defect increasing intracellular sodium is probably an innate factor in hypertension.

Our findings confirm genetic transmission of essential hypertension and show that defective sodium-potassium cotransport has the features of an autosomal, monogenic, and dominant trait. A similar prevalence of positive erythrocyte test results (abnormal cotransport) was found in one or more members of each generation of hypertensive families, and population studies showed positive test results in $53.6 \%$ and $73.7 \%$ of subjects with one and both parents hypertensive, respectively. These percentages are very close to the theoretical $50 \%$ and $75 \%$ for monogenic and dominant Mendelian transmission.

The mode of inheritance of essential hypertension remains to be determined. The profile of blood-pressure distribution curves has suggested a polygenic mechanism, ${ }^{1}$ whereas results of individual family studies, as performed here, have suggested a monogenic or oligogenic phenomenon ${ }^{2}$ similar to that described in primary hypertension in rats, where the major $\mathrm{Ht}$ gene was individualised..$^{16}$ This uncertainty clearly reflects the complexity of a multifactorial disease.

Since the abnormality of the erythrocyte membrane apparently indicates a genetic susceptibility to hypertension (de Mondonca $\vec{\oplus}$ et al (in press)), and since excess sodium intake is a major. environmental factor, ${ }^{17}$ the erythrocyte test may have important consequences. Performing the test on young children of hypertensive parents may provide the basis for a selective prevention programme: restriction of sodium in the diet and regular medical care in later life, particularly during oestrogen contraception and $\Phi$ pregnancy, should be recommended for those with a positive $\vec{F}$ result. The erythrocyte test may also help to explain the unequal $\frac{0}{3}$ prevalence of essential hypertension in various populations, ${ }^{17}$ which may be related to genetic or environmental differences. If prevalences of the erythrocyte abnormality were similar in different populations environmental factors would be sought; but if prevalences varied genetic factors would be suspected. In this respect it would be interesting to establish the prevalence of positive erythrocyte test results in populations with a high incidence of hypertension, such as the black population or northern Japanese.

Of the 90 blood donors in our series, $36(40 \%)$ had a positive 을 erythrocyte test result. It would be interesting to find a similar $N$ prevalence in northern Japanese, in whom the proportion with $D$ essential hypertension is also $40 \%{ }^{18}$; this would suggest that the massive intake of sodium by northern Japanese leads to full expression of the genetic defect.

Several investigators have suggested that the gene(s) coding for essential hypertension is associated with those coding for certain blood cell group systems. An increased frequency of HLA-A28, B27, and BW15 was thus observed in sustained $\stackrel{\oplus}{\leftrightarrow}$ essential hypertension. ${ }^{19}$ Similarly, essential hypertensives were reported to have a low frequency of the $S$ gene and a high 0 frequency of the s gene. ${ }^{20}$ These data were obtained by statistical $\vec{D}$ comparison of large numbers of normotensive and hypertensive $\frac{O}{\mathbb{D}}$ subjects-which relies on chance alone-in relation to the high $\cong$ frequency of both essential hypertension and certain group systems in all populations. Our investigation performed \& longitudinally in individual families obviated the possibility of error from inappropriate statistical analysis. The genes coding $\overline{0}$ for blood groups Duffy and Rh, MNS, P, and ABO are located $户$ on the I, II, IV, and IX pairs of chromosomes respectively, and 
the gene coding for the HLA system is located on the VI pair. A close association of one of these genes with the erythrocyte membrane abnormality and with hypertension would have been interesting on both theoretical and practical grounds. From our results, however, the abnormal gene(s) responsible for the essential hypertension does not appear linked to any of the major group systems studied.

Our findings suggest that the erythrocyte sodium-potassium cotransport deficiency is a biochemical abnormality characteristic of essential hypertension; this warrants further investigation in genetic studies of the disease.

We thank Dr L Degos (Hôpital St Louis, Paris) and Dr P Rougier (Hôpital St Antoine, Paris) for laboratory facilities.

\section{References}

${ }^{1}$ Hamilton M, Pickering GW, Roberts JAF, Sowry GSC. The aetiology of essential hypertension. IV. The role of inheritance. Clin Sci $1954 ; 13$ : 273.

2 Platt R. Heredity in hypertension. Lancet 1963 ; : 899.

3 Garay RP, Meyer P. A new test showing abnormal net $\mathrm{Na}^{+}$and $\mathrm{K}^{+}$ fluxes in erythrocytes of essential hypertensive patients. Lancet 1979;i: 349.

4 Garay RP, Elghozi JL, Dagher G, Meyer P. Laboratory distinction between essential and secondary hypertension by measurement of erythrocyte cation fluxes. N Engl f Med 1980;32:769.

5 De Mendonca M, Grichois ML, Garay RP, Sassard J, Ben-Ishay D, Meyer $\mathrm{P}$. Abnormal net $\mathrm{Na}^{+}$and $\mathrm{K}^{+}$fluxes in erythrocytes of three varieties of genetically hypertensive rats. Proc Natl Acad Sci USA 1980; 77:4283.

6 Garay RP, Dagher G, Pernollet MG, Devynck MA, Meyer P. Inherited defect in a $\mathrm{Na}^{+}-\mathrm{K}^{+}$co-transport system in erythrocytes from essential hypertensive patients. Nature 1980;284:281.

Canessa M, Adragna N, Solomon HS, Connolly TM, Tosteson DC. Increased sodium-lithium countertransport in red cells of patients with essential hypertension. N Engl f Med 1980;302:772.

${ }^{8}$ Rougier P, Salmon C. La pratique de l'agglutination des erythrocytes. Paris: Masson and Co, 1980:96.

9 Dausset J. Iso-leuco-anticorps. Acta Haematol (Basel) 1958;20:156.

10 Andre JL, Deschamps JP, Guegen R. Pression artérielle chez l' enfant. Valeurs rapportées à la taille. Nouv Presse Med 1980;9:1958.

11 Morton NE. Sequential tests for the detection of linkage. Am $\mathcal{F}$ Hum Genet $1955 ; 7: 277$.

12 Gutmann MC, Benson $H$. Interaction of environmental factors and systemic arterial blood pressure: a review. Medicine (Baltimore) 1971; 50:543.

${ }^{13}$ Loggie JMH, New MI, Robson A. Hypertension in the pediatric patient: a reappraisal. F Pediatr 1979;94:685.

14 Kwan CY, Belbeck L, Daniel EE. Abnormal biochemistry of vascular smooth muscle plasma membrane isolated from hypertensive rats. Mol Pharmacol 1980;17:137.

15 Jones AW. Reactivity of ion fluxes in rat aorta during hypertension and circulatory control. Fed Proc 1974 ;33:133.

16 Tanase H, Suzuki Y, Yamori Y. Genetic control of blood pressure in hypertensive diseases. In: Yamori Y, Lovemberg W, Frei E, eds. Prophylactic approach to hypertensive disease. New York: Raven Press, 1979:115.

17 Dahl LK. Salt intake and hypertension. In: Genest J, Koiw E, Kuchel O, eds. Hypertension. New York: Raven Press, 1977:548.

${ }^{18}$ Hatano S. Hypertension in Japan: a review. In: Paul O, ed. Epidemiology and control of hypertension. Stuttgart: Thieme Verlag, 1975:63.

19 Kristensen BO, Andersen PL, Lamm LU, Kissmeyer-Nielsen F. HLA antigens in essential hypertension. Tissue Antigens 1977;10:70.

${ }^{20}$ Miller JZ, Grim CE, Conneally PM, Weinberger MH. Association of blood groups with essential and secondary hypertension, a possible association of the MNS system. Hypertension 1979;1:493.

(Accepted 2 February 1981)

\section{SHORT REPORTS}

\section{Atypical case of alcohol-induced Cushingoid syndrome}

True alcohol-induced Cushingoid syndrome invariably resolves completely after several weeks of abstinence. ${ }^{12}$ We report a case of apparent pituitary-dependent Cushing's syndrome in an alcoholic in which there was evidence of hypercorticosteroidism over nine weeks after complete alcohol withdrawal, but which responded to a short course of metyrapone with no relapse.

\section{Case report}

A 59-year-old woman with a long history of alcoholism and whose recent intake was one bottle of sherry daily was admitted because of extensive bruising of her legs. On examination she was obese (weight $59 \mathrm{~kg}$ ) and plethoric, with hirsutism, thin skin, and limb bruising. Blood pressure was 140/80 $\mathrm{mm} \mathrm{Hg}$, but subsequent readings were lower. She had numerous spider naevi, facial telangiectasia, hepatomegaly, and ankle oedema.

Haemoglobin concentration was $12 \cdot 2 \mathrm{~g} / \mathrm{dl}$ mean corpuscular volume $114 \mathrm{ff}$ $\left(114 \mu \mathrm{m}^{3}\right)$. Serum vitamin $B_{12}$, folate, and fasting lipid concentrations were normal, as was a chest radiograph. Liver function values, which were abnormal on admission (raised serum bilirubin concentration, low serum albumin concentration, and raised serum alkaline phosphatase, aspartate transaminase, and $\gamma$-glutamyltranspeptidase activities), became normal within four weeks. Prothrombin ratio was 1.4 . Serum sodium concentration was $138 \mathrm{mmol}(\mathrm{mEq}) / 1$, serum potassium concentration $2.9 \mathrm{mmol}(\mathrm{mEq}) / \mathrm{l}$, and blood urea concentration $2.0 \mathrm{mmol} / 1(12.0 \mathrm{mg} / 100 \mathrm{ml})$. Blood sugar concentration was $11.3 \mathrm{mmol} / \mathrm{l}(204 \mathrm{mg} / 100 \mathrm{ml})$ with glycosuria.

Serum cortisol concentrations measured by fluorometry during the first week and while receiving spironolactone were $4100 \mathrm{nmol} / 1(149 \mu \mathrm{g} / 100 \mathrm{ml})$ at $9 \mathrm{am}$ (normal $160-660 \mathrm{nmol} / 1 ; 6-24 \mu \mathrm{g} / 100 \mathrm{ml}$ ) and $4600 \mathrm{nmol} / 1$ (167 $\mu \mathrm{g} / 100 \mathrm{ml}$ ) at $10 \mathrm{pm}$; measured by radioimmunoassay the next week, however, values were $950 \mathrm{nmol} / \mathrm{l}(34 \mu \mathrm{g} / 100 \mathrm{ml}$ ) at $9 \mathrm{am}$ (normal 200-700 $\mathrm{nmol} / \mathrm{l} ; 7-25 \mu \mathrm{g} / 100 \mathrm{ml}$ ) and $740 \mathrm{nmol} / \mathrm{l}(27 \mu \mathrm{g} / 100 \mathrm{ml}$ ) at $10 \mathrm{pm}$ (normally under $140 \mathrm{nmol} / 1 ; 5 \mu \mathrm{g} / 100 \mathrm{ml}$ ). Two weeks after stopping spironolactone serum cortisol concentrations measured by fluorometry were $1050 \mathrm{nmol} / \mathrm{l}$ $(38 \mu \mathrm{g} / 100 \mathrm{ml})$ at $9 \mathrm{am}$ and $1130 \mathrm{nmol} / 1(41 \mu \mathrm{g} / 100 \mathrm{ml})$ at $10 \mathrm{pm} ; 24$-hour urine collection yielded a cortisol concentration (also measured by fluorometry) of $7314 \mathrm{nmol} / 1(265 \mu \mathrm{g} / 100 \mathrm{ml})$. Serum adrenocorticotrophic hormone concentration at $9 \mathrm{am}$ was $131 \mathrm{ng} / 1$ (normal 10-80 $\mathrm{ng} / \mathrm{l}$ ). Three weeks after stopping spironolactone serum cortisol values after $2 \mathrm{mg}$ dexamethasone for two days did not suppress (fluorometry: $760 \mathrm{nmol} / 1(28 \mu \mathrm{g} / 100 \mathrm{ml}$ ) a $9 \mathrm{am}$ and $1310 \mathrm{nmol} / 1(47 \mu \mathrm{g} / 100 \mathrm{ml})$ at $10 \mathrm{pm})$, but adequate suppression occurred after $8 \mathrm{mg}(350 \mathrm{nmol} / 1(13 \mu \mathrm{g} / 100 \mathrm{ml})$ at $9 \mathrm{am}, 150 \mathrm{nmol} / 1(5 \mu \mathrm{g} /$ $100 \mathrm{ml}$ ) at $10 \mathrm{pm}$ ).

Two months after total abstinence (she was bedbound with no access to alcohol) there were still physical and biochemical features of apparent Cushing's syndrome, with loss of diurnal variation and raised serum cortisol values, and pituitary adenoma was suspected. Metyrapone $500 \mathrm{mg}$ thrice daily was begun, and the serum cortisol concentration fell to normal within six days. Skull radiography, tomography of pituitary fossa, perimetry, brain scan, and computed tomography showed no evidence of pituitary adenoma. After one month the metyrapone was stopped and she was clinically and biochemically better, with improved facial appearance and skin changes and loss of $8 \mathrm{~kg}$. Electrolyte and blood sugar concentrations were normal. Serum cortisol and biochemical values remained normal three, six, and 12 month later with no treatment except complete abstinence.

\section{Comment}

Over 20 cases of alcohol-induced Cushingoid syndrome have been reported, invariably reversing within several weeks of alcohol withdrawal. ${ }^{1-5}$ Physical signs or biochemical features, or both, had aroused suspicion of Cushing's syndrome, confirmed by loss of normal diurnal variation and raised serum cortisol values. When measured, adrenocorticotrophic hormone concentrations were raised in some patients. ${ }^{14}$ Response to low-dose dexamethasone was also variable, some patients showing normal suppression and others not. Response to the high-dose dexamethasone suppression test has not been reported before.

Although hypercorticosteroidism in alcoholics may be due to a lower metabolic clearance rate of cortisol or to decreased production of cortisol-binding globulin resulting from hepatic dysfunction, this does not explain the loss of diurnal variation or that total rather than unbound cortisol values are raised. In our patient adrenocorticotrophic hormone concentration was raised and production of cortisols was suppressed by high-dose but not low-dose dexamethasone, which clearly implicates a central mechanism affecting the pituitary or hypothalamus.

Our patient appeared to fulfil the criteria for typical pituitary- 